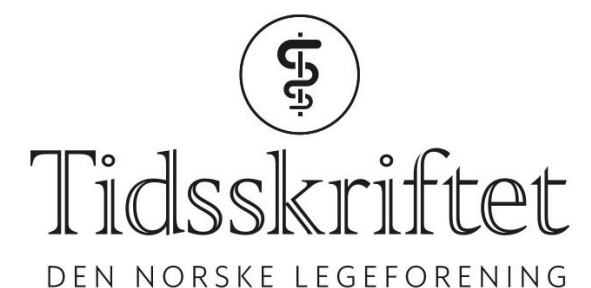

DEN NORSKE LEGEFORENING

\title{
Baserer synspunkter på myter
}

KOMMENTAR

LARS ØIVIND KRAFFT SANDE

E-post: lars@moloklinikken.no

Lars Øivind Krafft Sande er kardiolog.

\section{LARS KRISTIAN GULLESTAD}

Forfatterne har ikke oppgitt noen interessekonflikter.

Vår president, Marit Hermansen, innleder forbilledlig i sin kommentar «En legeforening for alle leger» i Tidsskriftet på nett 25 mai 2021 (1). Det er trygt å vite at Legeforeningen står bak alle sine medlemmer og det er lett å stille seg bak Legeforeningens mål om å hindre en økt todeling av helsetjenesten.

Men hva ligger egentlig i begrepet todeling av helsetjenesten?

Det er betalingsvilje for helsetjenester i befolkningen, og om lag 650 ooo har tegnet private helseforsikringer. Bekymringen om en todelt helsetjeneste handler om at flere kjøper undersøkelser og behandling hos private aktører, enten ved selvå betale eller ved å bruke helseforsikring. Dette skjer gjerne dersom det er lange ventetider i den offentlige helsetjenesten. Dette skaper et skille mellom pasienter basert på betalingsevne, der de med tykk lommebok eller behandlingsforsikring kan kjøpe seg ut av køen.

Når president Hermansen omtaler Fritt behandlingsvalg (FBV) i samme åndedrag som hun snakker om todeling, begår hun samme feilen som enkelte politikere, som baserer sine synspunkter på myter og ikke fakta.

FBV er ikke en privatiseringsreform. Det er først og fremst en viktig pasientrettighet, forankret i pasientrettighetsloven. Ordningen er en del av det offentlige tilbudet, under offentlig styring og under offentlig kontroll. Det offentlige beslutter hvilke pasienter som har rett til helsehjelp. Det offentlige beslutter hvilke behandlingssteder som kan tilby helsehjelpen. Og det offentlige fastsetter prisene for tjenestene som inngår i ordningen. Pasientene betaler vanlig offentlig egenandel uansett hvilket behandlingssted som velges. Ordningen er et eksempel på et godt innrettet samspill mellom den offentlige helsetjenesten og de private aktørene.

Vi har selv erfaring fra å tilby somatiske tjenester i FBV-ordningen. Pasientene som bruker ordningen, får kortere ventetid. De får raskere diagnose og behandling. Det gir kortere sykefravær, men også bedre livskvalitet, og helsegevinster. Helsehjelpen som gis gjennom ordningen er kostnadseffektiv. Vi får mer helse for hver krone. Det er også et viktig moment i en helsesektor som har økonomisk bærekraft som fremtidig utfordring.

Samtlige pasienter som utredes og behandles via FBV må henvises for å bli tildelt en 
rettighet. Det er derfor ingen autonomi eller «rekruttering av pasienter fra gata». I de somatiske løpene er risikoen for overdiagnostisering og overbehandling svært begrenset. Flere offentlige sykehus bruker ordningen aktivt, for å ivareta pasientene best mulig, når de selv har kapasitetsutfordringer.

Det er ikke tykkelsen på lommeboken som ligger til grunn for pasientenes mulighet til å benytte FBV. Fritt behandlingsvalg er en derfor en ordning som motvirker en todelt helsetjeneste.

Som gir alle pasienter med rett til helsehjelp, en rettighet til å velge behandlingssted. Ikke bare de med tykk lommebok eller helseforsikring.

Vi er tilhengere av å gjøre kloke valg, men vi håper også at Legeforeningen kan gjøre kloke valg. Formidle riktig, balansert informasjon og gjøre som vi leger skal gjøre; søke hjelp hos gode kolleger når vi ikke har nok innsikt eller erfaring til å sette en diagnose.

\section{LITTERATUR:}

1. Hermansen M. En legeforening for alle leger. Tidsskr Nor Legeforen 2021; 141. doi: 10.4045/tidsskr.21.0345. [PubMed][CrossRef]

Publisert: 28. juni 2021. Tidsskr Nor Legeforen. DOI: 10.4045/tidsskr.21.0467

(C) Tidsskrift for Den norske legeforening 2020. Lastet ned fra tidsskriftet.no 